\title{
Biogeography of Crustacea and Mollusca of the Subantarctic and Antarctic regions*
}

\author{
ANGELIKA BRANDT, KATRIN LINSE and UTE MÜHLENHARDT-SIEGEL \\ Zoological Institute and Zoological Museum, University of Hamburg, Martin-Luther-King-Platz 3, \\ D-20146 Hamburg, Germany.
}

\begin{abstract}
SUMMARY: The Joint Magellan "Victor Hensen" Campaign in 1994 focused on the biogeographic relationships of the Antarctic and Magellan fauna. The Peracarida and Mollusca sampled at 18 stations in the Beagle Channel by means of an epibenthic sledge were compared with the knowledge about the distribution of species data from the Falkland Islands, South Georgia, Antarctica and the Kerguelen. Peracarida were an important fraction of the macrobenthos and sampled in high numbers. About 105,000 individuals were collected with the epibenthic sledge. Until now about 40 species of Amphipoda, about 42 species of Isopoda, 24 species of Cumacea, eight species of Mysidacea, and 16 species of Tanaidacea were found. 118 mollusc taxa were identified, nine species of Aplacophora, 52 of Gastropoda, five of Scaphopoda and 52 of Bivalvia. Although the species present different distribution trends, the zoogeographic comparison for six larger taxa (four Mollusca and two Peracarida) showed that the species similarities decreased from the Magellan region towards the Falkland Islands and from South Georgia to Antarctica. The Magellanic Gastropoda showed similarities with the fauna of the Falkland Islands and South Georgia (31-37\%), whereas the Bivalvia were more similar to the Antarctic fauna (29\%). With regard to Crustacea, $10 \%$ of Antarctic Isopoda species were also found in the Magellan region; the Weddell Sea and East Antarctica, and South Georgia and the Antarctic Peninsula shared most species of both Cumacea and Isopoda, whereas the lowest similarities were shown between Bellingshausen and Weddell Sea for the Isopoda, and interestingly between the Magellan region and South Georgia for the Cumacea. The highest degree of endemism of the Isopoda and Cumacea was found in the Magellan region, where as a consequence of the opening of the Drake Passage many new species seem to have evolved in these taxa.
\end{abstract}

Key words: Zoogeography, Mollusca, Crustacea, Magellan region, Antarctica.

RESUMEN: LA BIOGEOGRAFÍA DE CRUSTACEA Y MOLLUSCA DE LAS REGIONES SUBANTÁRTICA Y ANTÁRTICA. - La campaña multidisciplinar realizada en el año 1994 a bordo del "Victor Hensen", se enfocó al estudio de las relaciones biogeográficas entre la fauna de la zona magallánica y la Antártida. Se compararon los datos obtenidos a partir del muestreo de peracáridos y moluscos llevado a cabo en 18 estaciones en el Canal del Beagle mediante un patín epibentónico, con los datos existentes sobre la distribución en las Islas Malvinas, Georgia del Sur, Kerguelen y la Antártida. Los peracáridos representaron una fracción importante del macrobentos y se muestrearon en grandes cantidades. Se colectaron alrededor de 105.000 especímenes con el patín epibentónico. Hasta ahora se han encontrado alrededor de 40 especies de anfípodos, cerca de 42 especies de isópodos, 24 especies de cumáceos, 8 especies de misidáceos y 16 especies de tanaidáceos. Se identificaron 118 taxones de moluscos, 9 especies de aplacóforos, 52 especies de gastrópodos, 5 especies de escafópodos y 52 especies de bivalvos. Aunque las especies presentaron patrones de distribución muy diferentes, la comparación zoogeográfica realizada con 6 taxones (4 moluscos y 2 peracáridos) muestra, en el caso de moluscos, que la similaridad entre especies disminuye desde la región magallánica hasta las Islas Malvinas y desde Georgia del Sur hasta la Antártida. Los gasterópodos magallánicos muestran similaridad con la fauna de las Islas Malvinas y Georgia del Sur (31-37 \%), mientras que los bivalvos fueron más similares a los pertenecientes a la fauna antártica (29\%). En relación a Crustacea, 10 \% de las especies de isópodos antárticos fueron también encontrados en la región magallánica. El Mar de Weddell, la Antártida oriental, Georgia del Sur y la Península Antártica compartieron la mayoría de las especies de cumáceos e isópodos; similitudes más bajas se mostraron entre los isópodos de Bellinghausen y el Mar de Weddell, e interesantemente para los cumáceos entre la región magallánica y Georgia del Sur. El alto grado de endemismo de los isópodos y cumáceos de la región magallánica señalaría a este taxón como un foco de radiación con especies que evolucionaron in situ despues de la apertura del Paso de Drake.

Palabras clave: Zoogeografía, Mollusca, Crustacea, región magallánica, Antártida.

*Accepted April 29, 1999. 


\section{INTRODUCTION}

The zoogeography of the fauna of the Magellan region is particularly important with respect to the Antarctic faunal composition, as South America was the last continent that separated from Gondwana some 30 to 20 my ago (Kennett, 1977; Crame, 1992). To what extent the presence of species corresponds between the Magellan area, the islands of the Scotia Arc, the Antarctic Peninsula and the high Antarctic, is of utmost interest for biogeographic and evolutionary questions,

The first investigations in the Magellan region, especially in the Beagle Channel date back to the 19th century (Deshayes, 1854; Hupé, 1854; Philippi, 1855; Smith, 1881; Mabille and Rochebrune, 1889; Dall, 1890). For example King and Broderip (1831) published the first larger account of Mollusca from the Magellan Strait and the coast of Tierra del Fuego, about 50 years after the first description of eleven Chilean molluscan species (Molina, 1782). Five years later Darwin passed the Beagle Channel on board the vessel "Beagle". Few investigations followed, some important ones were the expeditions and results of "The Hamburgische Magellanische Sammelreise" 1892/93 (Panning, 1957), the "Vema" expedition 1958-1961 of the Lamont Geological Observatory, USA (Bacescu-Mester, 1967; Bacescu and Muradian, 1974), the "Challenger" (Smith, 1885), the "Belgica" (Pelseneer, 1903), the Scottish Antarctic Expedition (Melvill and Standen, 1907, 1912), the "Albatross" (Dall, 1908) and the "Discovery" (Powell, 1951; Dell, 1964).

The most extensive and recent accounts of the Antarctic macrofauna and special macrofaunal taxa have been published recently, after modern research vessels, such as RV "Polarstern" were used for the logistics (e.g. Voß, 1988; Mühlenhardt-Siegel, 1989; Hain, 1990; Rauschert, 1990; Brandt, 1991). In the Magellan area fewer recent investigations have been undertaken mostly on special macrofaunal groups (e.g. Winkler, 1994; Linse, 1997; Schrödl, 1997). First results of an international joint venture in the Magellan Strait and the Beagle Channel have been published in Arntz and Gorny (1996), cf. also Brandt et al. (1997) and Linse and Brandt (1998). Besides these more extensive accounts on the Antarctic and Magellanic macro- and megafauna, many other taxonomic and faunistic reports have to be taken into account, which are scattered in a widely distributed literature. Therefore we are focusing on two important taxa (in terms of abundance and biomass) in this paper, the Mollusca and the Crustacea Peracarida. As the knowledge of the zoogeography of these two taxa is quite extensive, due to the tremendous amount of species, we can only present some representative examples.

\section{MATERIAL AND METHODS}

Macrofauna and megafauna samples were taken during the Joint Magellan "Victor Hensen" Campaign in November 1994. Crustacea Peracarida and Mollusca were collected with an epibenthic sledge (EBS), which was modified after Rothlisberg and Pearcy (1977), at 18 stations in the Beagle Channel. The complete sledge samples were analyzed and peracarid and mollusc specimens were counted and identified to genus or species level if possible. On board the vessel, the samples were fixed in $4 \%$ buffered formalin and later washed into ethanol (70 $\%)$. The zoogeographic comparison with other Subantarctic and high Antarctic areas was done on the basis of all available taxonomic publications and larger accounts on the Antarctic fauna (see above).

\section{RESULTS}

\section{Species richness and abundance}

In the Beagle Channel about 35,000 Mollusca and 105,000 Crustacea Peracarida were sampled with the epibenthic sledge (Table 1). For comparisons between stations, these values were calculated for a trawled distance of $1000 \mathrm{~m}^{2}$, yielding a total of 107,413 specimens of Mollusca and 368,095 specimens of Peracarida. Bivalvia and Gastropoda were most speciose, with 52 species each, followed in species number by the Aplacophora with 9 and the Scaphopoda with 5 species, respectively (Linse, 1999). Within the Peracarida, though not all species have yet been determined, 8 species of Mysidacea, 16 species of Tanaidacea, and 24 species of Cumacea (Mühlenhardt-Siegel, 1999) were distinguished. Within the Isopoda 42 species have so far been identified from the Beagle Channel material, however, this number will increase when all material is analyzed (for comparison, Lorenti and Mariani [1997] found 24 isopod species in the Magellan Straits during a survey in 1991). We expect more than 40 amphipod species and this species number will certainly increase to around 100 once the iden- 
TABLE 1. - Species richness of peracarid (Amphipoda, Cumacea, Isopoda, Mysidacea, Tanaidacea) and molluscan taxa (Aplacophora, Gastropoda, Scaphopoda, Bivalvia) in the Beagle Channel. S Per = species number of all peracarid taxa; $\mathrm{S}$ Mol $=$ species number of the molluscan taxa; haul = length of the haul in $\mathrm{m}$.

\begin{tabular}{|c|c|c|c|c|c|c|c|c|c|c|c|c|c|}
\hline Station & Amphip & Cumac. & Isop. & Mysid. & Tanaid. & S Per. & Aplaco. & Gastro. & Scapho. & Bival. & S Moll. & $\underset{(\mathrm{m})}{\text { depth }}$ & $\begin{array}{c}\text { haul } \\
(\mathrm{m})\end{array}$ \\
\hline \multicolumn{14}{|l|}{ east } \\
\hline $49-1206$ & $>20$ & 7 & 12 & 2 & 4 & $>45$ & 0 & 14 & $\mathbf{0}$ & 10 & 24 & 66 & 186 \\
\hline $48-1200$ & $>22$ & 6 & 24 & 2 & 3 & $>57$ & 0 & 25 & 0 & 19 & 44 & 40 & 428 \\
\hline $43-1184$ & $\sim 10$ & 4 & 17 & 3 & 1 & $\sim 35$ & 0 & 3 & 0 & 5 & 8 & 110 & 246 \\
\hline $43-1194$ & $\sim 3$ & 0 & 1 & 0 & $\mathbf{0}$ & $\sim 4$ & 0 & $\mathbf{0}$ & 0 & 2 & 2 & 118 & 608 \\
\hline $43-1197$ & $\sim 11$ & 6 & $\mathbf{0}$ & 1 & 0 & $\sim 18$ & 0 & $\mathbf{0}$ & 0 & $\mathbf{0}$ & 0 & 117 & 152 \\
\hline $42-1178$ & $\sim 13$ & 2 & 15 & 0 & 3 & $\sim 33$ & 0 & 12 & 0 & 16 & 28 & 25 & 132 \\
\hline $41-1213$ & $\sim 41$ & 8 & 31 & 1 & 5 & $\sim 86$ & 3 & 36 & 0 & 30 & 69 & 63 & 316 \\
\hline $39-1237$ & $\sim 8$ & 4 & 10 & 2 & 1 & $\sim 25$ & 0 & 4 & 0 & 12 & 16 & 103 & 169 \\
\hline $37-1246$ & $\sim 11$ & 8 & 1 & $\mathbf{0}$ & 3 & $\sim 23$ & 5 & 4 & 5 & 22 & 36 & 253 & 400 \\
\hline $37-1247$ & $>16$ & 16 & 13 & 1 & 5 & $>51$ & 7 & 17 & 1 & 23 & 48 & 100 & 410 \\
\hline $37-1248$ & $>23$ & 14 & 6 & 0 & 6 & $>50$ & 4 & 6 & 1 & 19 & 30 & 217 & 247 \\
\hline $37-1253$ & $>24$ & 17 & 10 & 5 & 2 & $>58$ & 0 & 3 & 1 & 13 & 17 & 265 & 256 \\
\hline $33-1257$ & 3 & 3 & 3 & $\mathbf{0}$ & 1 & 10 & 1 & 0 & 1 & 5 & 7 & 350 & 295 \\
\hline $33-1261$ & 0 & 4 & 1 & 1 & $\mathbf{0}$ & 6 & 0 & $\mathbf{0}$ & 0 & 5 & 5 & 120 & 319 \\
\hline $31-1263$ & $\sim 11$ & 8 & 1 & 1 & 0 & $\sim 21$ & 5 & 7 & 4 & 21 & 37 & 665 & 266 \\
\hline $29-1270$ & $\sim 12$ & 10 & $\mathbf{0}$ & 1 & 1 & $\sim 24$ & 0 & 11 & 2 & 17 & 30 & 135 & 379 \\
\hline $28-1279$ & $\sim 11$ & 6 & 4 & 1 & 1 & $\sim 23$ & 4 & 7 & 3 & 8 & 19 & 580 & 178 \\
\hline $19-1307$ & 1 & 5 & 2 & 0 & 0 & 8 & $\mathbf{0}$ & 0 & 1 & 2 & 3 & 271 & 347 \\
\hline west & & & & & & & & & & & & & \\
\hline
\end{tabular}

tification is completed. More than 120 species of amphipods have been discriminated in the Beagle Channel material, collected with a different sampling device (Rauschert, pers. comm; De Broyer and Rauschert, 1999).

\section{Zoogeographical analysis}

Due to the enormous biodiversity of the Crustacea Peracarida and Mollusca in both Subantarctic and Antarctic regions, only a few examples of the zoogeography of both taxa can be presented here.

While the zoogeographic comparison of the Mollusca has been made for all 4 larger taxa, the comparison between the Magellan region and the Subantarctic and Antarctic within the Peracarida had to be restricted to the Cumacea and Isopoda.

In Table 2a the species overlaps of all mollusc species from the Beagle Channel and the Magellan area (MA, shaded column) found in the EBS samples are presented, in Table $2 b$ only the new records. It is obvious that the Magellan area shares most species with the Patagonian shelf and the Falkland Islands, whereas the number of species overlaps decreases via the islands of the Scotia Arc, from 24 species on South Georgia, which are shared with the Magellan area to 21 species with the Antarctic continent and only 7 species, which can also be found on Kerguelen Island. Interestingly, within the new records for the Magellan area we find a different picture, as a higher number of species is shared here with the Antarctic continent,
TABLE 2. - Species overlaps of the Mollusca between selected regions of the Magellan area and the Antarctic. a) comparison of molluscan species of the Beagle Channel and surrounding regions; b) species overlaps of the new records. $\mathrm{MA}=$ Magellan area; $\mathrm{PT}=$ Patagonia; FI = Falkland Islands; $S G=$ South Georgia; ANT = Antarctic continent including the Antarctic Peninsula and South Shetland Islands but without the Subantarctic; KI = Kerguelen.

\begin{tabular}{lrrrrrr}
\hline a & MA & PT & FI & SG & ANT & KI \\
\hline $\begin{array}{l}\text { Aplacophora } \\
\text { Gastropoda }\end{array}$ & 52 & 0 & 0 & 0 & 0 & 0 \\
$\begin{array}{l}\text { Scaphopoda } \\
\text { Bivalvia }\end{array}$ & 52 & 15 & 19 & 16 & 4 & 2 \\
Sum & 118 & 29 & 30 & 24 & 21 & 7 \\
\hline b & MA & PT & FI & SG & ANT & KI \\
\hline $\begin{array}{l}\text { Aplacophora } \\
\text { Gastropoda }\end{array}$ & 7 & 0 & 0 & 0 & 0 & 0 \\
Scaphopoda & 11 & 4 & 5 & 3 & 1 & 0 \\
Bivalvia & 22 & 0 & 0 & 0 & 0 & 0 \\
Sum & 42 & 5 & 7 & 7 & 10 & 4 \\
\hline
\end{tabular}

as compared to the Falkland Islands and the Islands of the Scotia Arc.

For example the bivalves Solecardia antarctica Hedley, 1911 and Kellia simulans Smith, 1907 have only been recorded from the Ross Sea and the South Shetland Islands until today, whereas Thracia meridionalis Smith, 1885 has been recorded circumantarctically from the Antarctic continent, from South Georgia and from the Falkland Islands, from the South Orkney Islands and from the Kerguelen Islands. Cuspidaria infelix Thiele, 1912 recorded in 
TABLE 3. - Species overlaps between the Magellan and Antarctic regions within the Isopoda and Cumacea.

\begin{tabular}{lcr}
\hline & Isopoda & Cumacea \\
\hline Magellan region/South Georgia & 25 & 2 \\
Magellan region/Antarctic Penins. & 22 & 3 \\
South Georgia/Antarctic Penins. & 30 & 10 \\
Antarctic Penins./Bellingshausen S. & 28 & $?$ \\
Antarctic Penins./Weddell S. & 31 & 7 \\
Bellingshausen S./Weddell S. & 16 & $?$ \\
Weddell S./Ross S. & 20 & 8 \\
Weddell S./East Antarctic & 33 & 15 \\
Ross S./East Antarctic & 25 & 6 \\
\end{tabular}

the High Antarctic circumantarctically, from Bouvet Island, from the South Orkney Islands and from South Georgia, has also been found in the Magellan area. Most of the Gastropoda recorded for the Magellan region for the first time are also known from the Patagonian shelf and the Falkland Islands, for example Colpospirella algida (Melvill and Standen, 1912), Mathilda cf. malvinarum (Melvill and Standen, 1907), Trophon cf. ohlini Strebel, 1905 and Eulimella cf. xenophyses (Melvill and Standen, 1912), or from South Georgia: Balcis subantarcticus (Strebel, 1908) and Cylichna georgiana Strebel, 1908. Omalogyra antarctica, only recorded from the High Antarctic so far, was also found in the Beagle Channel.

The species overlaps between the Magellan and selected Antarctic regions for the Cumacea and Isopoda are presented in Table 3. The Weddell Sea shares most species of both taxa with the East Antarctic, and also South Georgia and the Antarctic Peninsula show considerable overlaps in these taxa. The lowest species overlap within zoogeographic areas was reported between Bellingshausen and the Weddell Sea for the Isopoda and, interestingly, between the Magellan region and South Georgia in Cumacea. Contrary to this observation, the species overlaps for the Isopoda in these regions are moderately high.

For zoogeographic analyses of faunistic areas it is also crucial to know the percentage of endemic species of the different taxa. These are presented for the Magellan and Antarctic Isopoda and Cumacea in Table 4 ( $\mathrm{a}$ and b), as well as for Magellan molluscs (Table 4c). Both within the Isopoda and Cumacea we find the highest degree of endemism in the Magellan region, indicating that some sort of a radiation must have happened there similar to the radiation that occurred in the Antarctic within some isopod families (i.e. the Serolidae and Arcturidae) (Brandt,
TABLE 4. - Percentages of endemisms for selected regions: a) endemic species of Magellan and Antarctic Isopoda (Brandt unpublished, 1997); b) endemic species of Magellan and Antarctic Cumacea; c) endemic species of Magellan Mollusca.

a

Region sum $\mathrm{S}$ endemics \% endemism

\begin{tabular}{|c|c|c|c|}
\hline \multicolumn{4}{|l|}{ Magellan region } \\
\hline Magellan area & 104 & 40 & 40 \\
\hline Falkland I. & 70 & 22 & 31 \\
\hline \multicolumn{4}{|l|}{ Subantarctic } \\
\hline South Georgia & 49 & 9 & 18 \\
\hline South Sandwich I. & 16 & 5 & 31 \\
\hline South Orkney I. & 26 & 2 & 8 \\
\hline South Shetland I. & 91 & 23 & 25 \\
\hline Crozet I. & 31 & 5 & 16 \\
\hline Kerguelen I. & 80 & 28 & 35 \\
\hline Macquarie I. & 10 & 1 & 10 \\
\hline Auckland I. & 5 & 1 & 20 \\
\hline Campbell I. & 7 & 0 & 0 \\
\hline \multicolumn{4}{|l|}{ High Antarctic } \\
\hline Bellingshausen Sea & 40 & 2 & 5 \\
\hline Weddell Sea & 68 & 13 & 17 \\
\hline Ross Sea & 39 & 3 & 8 \\
\hline East Antarctic & 111 & 34 & 30 \\
\hline \multicolumn{4}{|l|}{$\mathrm{b}$} \\
\hline Region & sum $\mathrm{S}$ & endemics & $\%$ endemism \\
\hline Magellan area & 31 & 16 & 52 \\
\hline South Georgia & 16 & 4 & 25 \\
\hline South Orkney I. & 16 & 0 & 0 \\
\hline South Shetland I. & 20 & 0 & 0 \\
\hline Kerguelen I. & 20 & 8 & 40 \\
\hline Antarctic Penins. & 15 & 0 & 0 \\
\hline Weddell Sea & 29 & 7 & 24 \\
\hline Ross Sea & 11 & 2 & 18 \\
\hline East Antarctic & 32 & 5 & 16 \\
\hline $\mathrm{c}$ & sum $\mathrm{S}$ & endemics & $\%$ endemism \\
\hline Aplacophora & 9 & 9 & 100 \\
\hline Gastropoda & 52 & 25 & 48 \\
\hline Scaphopoda & 5 & 3 & 60 \\
\hline Bivalvia & 52 & 22 & 42 \\
\hline Sum & 118 & 59 & 50 \\
\hline
\end{tabular}

1991) or the amphipod family Iphimediidae (Watling and Thurston, 1989). On Campbell Island no endemic isopod species was sampled and in the Bellingshausen Sea only 2 species (5\%) of Isopoda are endemics. Kerguelen Island is characterized by $40 \%$ of endemic cumacean species, and at South Georgia and in the Weddell Sea about a quarter of all known Cumacea are endemics. Within the Mollusca the rate of endemism can only be presented (on the basis of own data) for the Magellan area. Due to the sampling of some new species of Aplacophora, the rate of endemism of this group is $100 \%$ in the Beagle Channel, and with $60 \%$ it is still high within the 
Scaphopoda. The Gastropoda and Bivalvia show a rate of endemism of less than $50 \%$ in the Beagle Channel.

\section{DISCUSSION}

The zoogeography of the selected species presented in Figure 1 shows different patterns. Many species differ quite considerably in the range of distribution: some are distributed circumantarctically, others are more or less restricted to the Subantarctic area, or to the Magellan region. The reasons for these zoogeographic differences can be manifold. Species, which are more mobile than others could for example be distributed circumantarctically more easily than tube dwellers or burrowing species or semiendobenthic or epibenthic species, which do not have good swimming capabilities. Circumantarctic species might also be phylogenetically older, or just very adaptable to different habitats or ecological niches. The distribution of species in the Magellan area at the Antarctic Peninsula or at some islands of the Scotia Arc could be the result of continental drift vicariance, initiated with the separation of South America from Antarctica and the completion of the deep water formation in the area of the Drake Passage. Continental drift vicariance is for example very likely for species of the genus Heteroserolis (Brandt, 1991; Wägele, 1994), which occurs off America and Australia. The high percentage of endemic species in the Magellan area documents that some species are restricted to the cold-temperate area of the southern tip of South America. It might be that these species only evolved after establishment of the Drake Passage, as they are not known either from the Subantarctic or the Antarctic until now, or that their present distribution is the result of dispersal events of the taxa, because "cooling events, as well as being a time when warmer water taxa moved away from Antarctica, may also have facilitated the expansion northwards of cool, stenothermal taxa which originated in the highest southern latitudes around Antarctica" (Clarke and Crame, 1992).

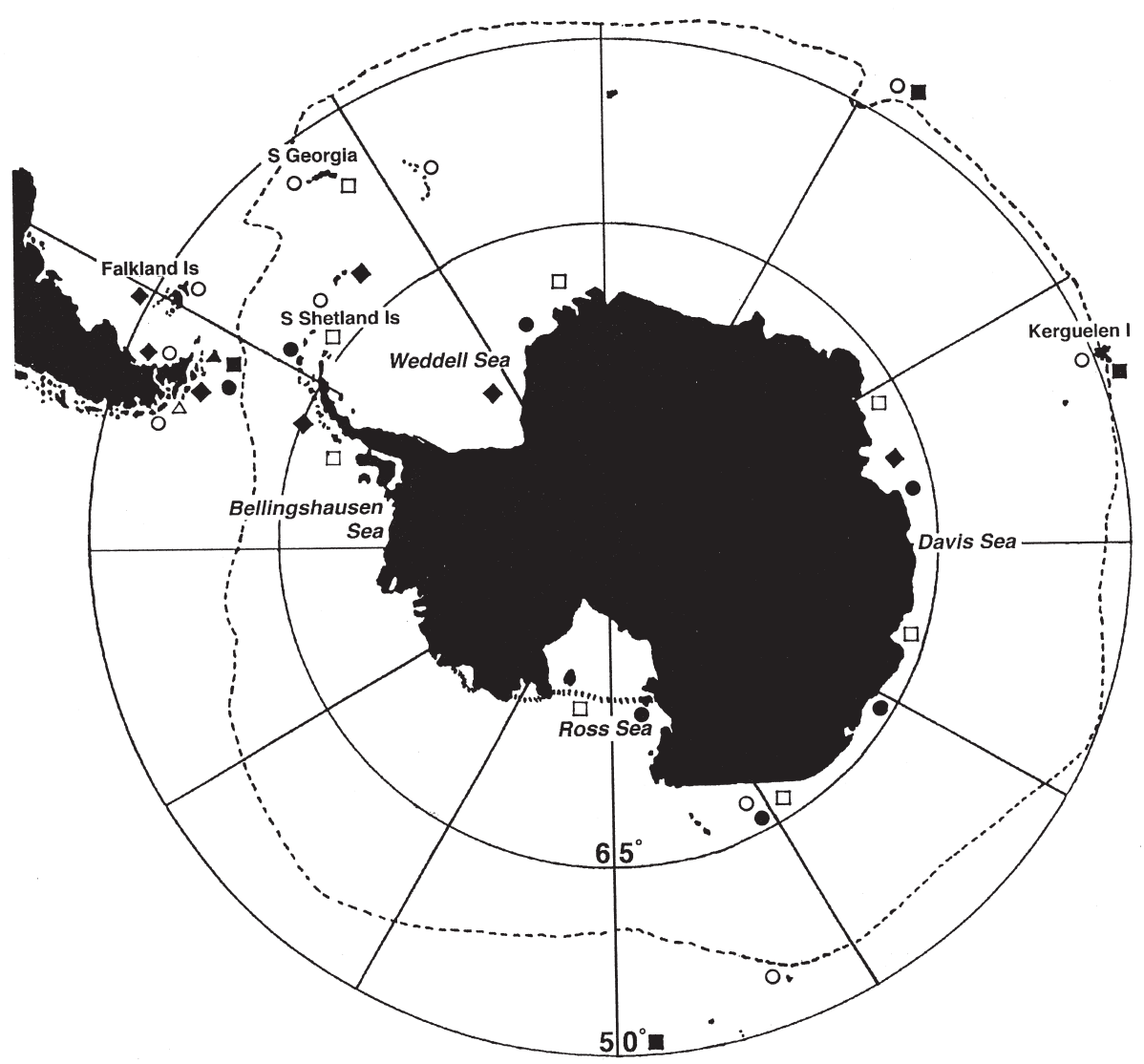

FIG. 1. - Zoogeographical distribution of selected molluscan and peracarid taxa in the Magellan region and around Antarctica. The symbols refer to the following species: q Falcidens sp. (Caudofoveata, Chaetodermatidae); $\pi$ Cyclostrema crassicostatum Strebel, 1908 (Gastropoda, Cyclostrematidae); Limatula pygmaea (Philippi, 1845) (Bivalvia, Limidae); Limatula similliana (Thiele, 1912) (Bivalvia, Limidae); Leucon assimilis Sars, 1887 (Cumacea, Leuconidae); $\square$ Glyptonotus antarcticus Eights, 1853 (Isopoda, Chaetiliidae), $\square$ Acutiserolis bromleyana (Suhm, 1874) (Isopoda, Serolidae). 
Table 3 shows that the lowest species overlap within zoogeographic areas for the Isopoda was reported between the Bellingshausen and the Weddell Seas, whereas for the Cumacea the overlap in species composition between the Magellan region and South Georgia was lowest, which is striking. However, this finding might be just accidental on the one hand, because not much research has been done on the cumacean fauna of the Falkland Islands, nor has the Bellingshausen Sea been investigated very well (see question mark in Table 3 ). On the other hand, it is astonishing also that the overlap between the Magellan area and the Antarctic Peninsula is low (only 3 species) within the Cumacea. Seven of 73 Cumacea species are found in both the Magellan region and Antarctica. The overlap for this crustacean taxon is less than $10 \%$. This species composition of the Cumacea in the Magellan region and in Antarctic waters leads to the conclusion that Antarctica was probably not colonized from South America along the Scotia Arc, because otherwise one would expect a higher species overlap on the islands in the Scotia Arc (for species list see Mühlenhardt-Siegel, 1999). In comparison, the mysids' species overlap between Antarctic and the Magellan region is higher (12\%; Brandt et al., 1998).

Within the Mollusca the species overlap between the Magellan area, Patagonia and the Falkland Islands is high, especially for the Gastropoda (29$37 \%$ ). For example, some Magellan shallow-water species such as the Trochidae Photinula and Photinastoma or the Muricidae Xymenopsis and Fuegotrophon (Powell, 1965) only colonize the continental shelf and occur from the Magellan region to the Falkland Islands. Circum-subantarctic distribution could be caused by long-distance dispersal with the Circumpolar Current. Helmuth et al. (1994) proved that Gaimardia trapesina (Lamarck, 1819) can reach the Falkland Islands and South Georgia by kelp-rafting. Many molluscan species occurring on both sides of the Drake Passage show an eurybathic distribution. Dell (1972) and Hain (1989) discussed possible emergence of these species from the deep sea. The high endemism rate among the Aplacophora might be caused by the lack of samples from other regions collected by an adequate gear to catch these small animals.

At present it is not possible to present a unified zoogeography of Antarctic faunal taxa, as different strategies were followed by different taxa in the past. We can find taxa of a very wide, circumantarctic distribution, while others are restricted to certain zoogeographic subregions of the Southern Ocean, the Magellan area, the Subantarctic or the High Antarctic. Within some taxa we find radiation processes for some species groups, others show submergence or emergence processes from or down towards the deep sea, or species might easily have dispersed due to physiological preadaptations, pelagic larvae or drift stages, or due to the changing environment, with changing currents, temperature, salinity, nutrient supply, etc. Continental drift vicariance might be one potential reason for the distribution of species in geographically separated areas. Within the Mollusca and at least the Cumacea and Isopoda of the Peracarida, one or another of these processes might have influenced the present zoogeographical distribution of the species.

\section{ACKNOWLEDGEMENTS}

We are very grateful to the crew of the RV "Victor Hensen", who always helped with the sampling. Thanks are also due to the Alfred Wegener Institute for Polar and Marine Research for the invitation to the first author to join two legs of the Joint Magellan "Victor Hensen" Campaign.

\section{REFERENCES}

Arntz, W. and M. Gorny. - 1996. Cruise report of the Joint ChileanGerman-Italian Magellan "Victor Hensen" Campaign in 1994. Ber. Polarforsch., 190: 1-113.

Bacescu, M. and Z. Muradian. - 1974. Campylaspenis, Styloptocuma, Atlantocuma, new genera of Cumacea from the deep waters of the Atlantic. Rev. roum. Biol., Ser. Zool., 19 (2): 7178.

Bacescu-Mester, L. - 1967. Contribution to the knowledge of the genus Leptostylis Sars (Cumacea); three new species collected by the Vema expedition. Crustaceana, 13 (3): 265-274.

Brandt, A. - 1991. Zur Besiedlungsgeschichte des antarktischen Schelfes am Beispiel der Isopoda (Crustacea, Malacostraca). Ber. Polarforsch., 98: 1-240.

Brandt, A., K. Linse and U. Weber. - 1997. Abundance and diversity of peracarid taxa (Crustacea, Malacostraca) along a transect through the Beagle Channel, Patagonia. Polar Biol., 18: 83-90.

Brandt, A., U. Mühlenhardt-Siegel and V. Siegel. - 1998. An account of the Mysidacea (Crustacea, Malacostraca) of the Antarctic and Subantarctic Ocean. Antarct. Sci., 10 (1): 3-11.

Clarke, A. and J. A. Crame. - 1992. The Southern Ocean benthic fauna and climate change: a historical perspective. Phil. Trans. R. Soc. Lond. B, 338: 299-309.

Crame, A. -1992 . Evolutionary history of the polar regions. Hist. Biol., 6: 37-60.

Dall, W.H. - 1890. Scientific results of exploration by the U.S. Fish Commission steamer "Albatross", VII. Preliminary report on the collection of Mollusca and Brachiopoda obtained in 188788. Proc. U.S. Nat. Mus., 12: 219-362.

Dall, W.H. - 1908. The Mollusca and the Brachiopoda. Bull. Mus. Comp. Zool., 43: 205-487.

De Broyer, C. and M. Rauschert. - 1999. Biodiversity of the amphipod taxocoenoses (Crustacea) in the Magellan Region in comparison with the west and east Antarctic regions (preliminary 
results). Sci. Mar., 63(Supl. 1): 281-293.

Dell, R.K. - 1964. Antarctic and sub-Antarctic Mollusca: Amphineura, Scaphopoda, and Bivalvia. Disc. Rep., 23: 93250 .

Dell, R.K. - 1972. Antarctic Benthos. Adv, mar. Biol., 10: 1-216.

Deshayes, G.P. - 1854. Description of new shells from the collection of H. Cuming. Proc. Zool. Soc. London.

Hain, S. - 1989. Beiträge zur Biologie der beschalten Mollusken (Kl. Gastropoda \& Bivalvia) des Weddellmeeres, Antarktis. Doctoral thesis, Univ. Bremen.

Hain, S. - 1990. Die beschalten Mollusken (Gastropoda und Bivalvia) des Weddellmeeres, Antarktis. Ber. Polarforsch., 70: 1-181.

Helmuth, B., R.R. Veit and R. Holberton. - 1994. Long-distance dispersal of a subantarctic brooding bivalve (Gaimardia trapesina) by kelp-rafting. Mar. Biol., 120: 421-426.

Hupé, L.H. - 1854. Fauna chilense. Moluscos. In: C. Gay, Historia Física y Política de Chile. Zoologica 8, 499pp. Paris

Kennett, J.P. - 1977. Cenozoic evolution of Antarctic glaciation, the circum-Antarctic Ocean, and their impact on global palaeoceanography. J. Geophys. Res., 82: 3834-1411.

King, P.P. and W.J. Broderip. - 1831. Description of the Cirrhipedia, Conchifera and Mollusca formed by the officers of H.M.S. Adventure and Beagle employed between the years 1826 and 1830 in surveying the southern coasts of South America including the Straits of Magelhaens and the coast of Tierra del Fuego. Zool. J., 5: 332-349.

Linse, K. - 1997. Die Verbreitung epibenthischer Mollusken im chilenischen Beagle-Kanal. Ber. Polarforsch., 228: 1-131.

Linse, K. and A. Brandt. - 1998. Distribution of epibenthic Mollusca on a transect through the Beagle Channel (southern Chile). $J$. Mar. Biol. Ass. U.K., 78: 875-889.

Linse, K. - 1999. Abundance and diversity of Mollusca in the Beagle Channel. Sci.Mar., 63(Supl. 1): 391-397.

Lorenti, M. and S. Mariani. - 1997. Isopod assemblages in the Straits of Magellan: structural and functional aspects. Polar Biol., 18: 254-259.

Mabille, J. and A.T. Rochebrune. - 1889. Mollusques. Mission scientifique du Cap Horn, 1882-3. 6, Zoologie, 2: 1-143.

Melvill, J.C. and R. Standen. - 1907. The marine Mollusca of the Scottish National Antarctic Expedition. Trans. Roy. Soc. Edinb., 46: 119-157.

Melvill, J.C. and R. Standen. - 1912. The marine Mollusca of the Scottish National Antarctic Expedition. Part II. Trans. Roy. Soc. Edinb., 46: 333-366.

Molina, G.I. - 1782. Saggio sulloa atoria del Chile. Bologne.

Mühlenhardt-Siegel, U. - 1989. Antarktische Bivalvia der Reisen des FS "Polarstern" und des FFS "Walther Herwig" aus den Jahren 1984 bis 1986. Mitt. Hamb. Zool. Mus. Inst., 86: 153-178.

Mühlenhardt-Siegel, U. - 1999. On the biogeography of Cumacea - A comparison between South America, the Subantarctic Islands and
Antarctica: present state of art. Sci. Mar., 63(Supl. 1): 295-302.

Panning, A. - 1957. Beiträge zur Geschichte des Zoologischen Staatsinstituts und Zoologischen Museums, Hamburg. - Mitt. Hamb. Zool. Mus. Inst., 55: 1-23.

Pelseneer, P. - 1903. Mollusques (Amphineures, Gastéropodes et Lamellibranches). Résultat du Voyage du S.Y. „Belgica“ en 1897-1898-1899. Rap. Sci. Zool.: 1-85.

Philippi, R.A. - 1855. Observaciones sobre las conchas de Magallanes. Anales de la Univ. de Chile, Santiago.

Powell, A.W.B. - 1951. Antarctic and sub-Antarctic Mollusca: Pelecypoda and Gastropoda. Disc. Rep., 26: 49-196.

Powell, A.W.B. - 1965. Mollusca of the Antarctic and Subantarctic Seas. In: J. van Miegham and P. van Oye (eds.): Biogeography and Ecology in Antarctica, pp. 333-380. Junk, The Hague.

Rauschert, M. - 1990. Ergebnisse der faunistischen Arbeiten im Benthal von King George Island (Südshetlandinseln, Antarktis). Ber. Polarforsch., 76: 1-75.

Rothlisberg, P.C. and W.G. Pearcy. - 1977. An epibenthic sampler used to study the ontogeny of vertical migration of Pandalus jordani (Decapoda, Caridea). Fish. Bull. (Washington D.C.), 74: 994-997.

Schrödl, M. - 1997. Range extensions of Magellanic nudibranchs (Ophisthobranchia) into the Peruvian Faunal Province. Veliger, 40: $38-42$.

Schrödl, M. - 1999. Nudibranchia (Mollusca: Opisthobranchia) of the Magellanic Faunal Province: taxonomy, distributional checklist and zoogeographic relations. Sci. Mar., 63(Supl. 1): 409-416

Smith, A.E. - 1881. Mollusca and Molluscoidea. Account of the zoological collections made during the survey of H.M.S. "Alert" in the Straits of Magellan and on the coast of Patagonia. Proc. Zool. Soc., London: 22-44.

Smith, A.E. - 1885. Report on the Lamellibranchiata collected by H.M.S. "Challenger", during the years 1873-76. Reports on the Scientific Results of the Voyage of the H.M.S. "Challenger" (1873-1876) Zoology, 13: 1-341.

Voß, J. - 1988. Zoogeographie und Gemeinschaftsanalyse des Makrozoobenthos des Weddellmeeres (Antarktis). Ber. Polarforsch., 45: 1-145.

Wägele, J.W. - 1994. Notes on Antarctic and South American Serolidae (Crustacea, Isopoda) with remarks on the phylogenetic biogeography and description of new genera. Zool. $\mathrm{Jb}$. Syst., 121: 3-69.

Watling, L. and M.H. Thurston. - 1989. Antarctica as an evolutionary incubator: evidence from the cladistic biogeography of the amphipod family Iphimediidae. In: J. A. Crame (ed.), Origins and Evolution of the Antarctic Biota. Geolog. Soc. Spec. Publ., 47: 297-313.

Winkler, H. - 1994. Charaktierisierung der Isopodenfauna (Crustacea, Malacostraca) des Scotia Bogens aus biogeographischer Sicht: Ein multivariater Ansatz. Ber. Polarforsch., 139: 1-196. 